\title{
Exploration on the cultivation of young teachers' teaching ability in applied Undergraduate Universities
}

\author{
Haixia $\mathrm{Wu}$ \\ Hankou University, Wuhan 430212, China
}

\begin{abstract}
Young teachers are an important part of the teaching power of colleges and universities, as well as the reserve force of creativity and development in Colleges and universities. Its teaching ability directly affects the teaching quality of colleges and universities. The cultivation of young teachers is an important element in the construction of teaching staff in undergraduate colleges and universities. The school should take the application as the main goal of training talents, should implement a strict and complete teaching admittance system. Strengthening the training and in-service training for young teachers. In addition, the need to strengthen the linkages between enterprises and universities, the government's macro-control also plays a crucial role.

Keywords Application Young teachers Teaching ability Training path

With the development of society, higher education is becoming ever more popular. So the demand for teachers in Colleges and universities is also increasing, which has increased the demand for young teachers. The research on the communication between the school and the literature shows that there are a few problems existing in the teaching ability of the young teachers. These problems have severely affected the teaching ability of young teachers. To improve the teaching ability of young teachers has become the top priority of training young teachers.
\end{abstract}




\section{The composition of young teachers in Applied Undergraduate Colleges and Universities}

In the reform and opening up of the three university education stage (late $80 \mathrm{~s}$ to $90 \mathrm{~s}$; 90 s to the beginning of this century; at the beginning of this century so far), for the teaching ability of young teachers from the simple evaluation stage, the content of teaching ability to have certain understanding to the last stage, the establishment and perfection of the teaching evaluation stage, research the young teachers in higher education teaching ability gradually.[1]

\section{1 teaching cognitive ability}

The cognitive ability of teaching requires the teachers to better identify the teaching task, analyze the characteristics of the educated, and have a certain grasp of the teaching situation. Includes a comprehensive understanding of the school for the talent training objective and training ability, reasonable selection of materials and make evident the ability to choose, for teaching conditions, students' learning readiness and learning knowledge, judgment ability.

\section{2 teaching design abilities}

Teachers in the teaching work, according to the teaching objectives, set a good teaching content, as well as a certain arrangement of the teaching process. According to the teaching objectives, the curriculum objectives can be divided into specific teaching objectives. According to the teaching objectives, the author designs the explicit teaching activities, teaching methods, teaching methods and means.

\section{3 teaching practice abilities}

The ability of educating implementation refers to the ability of the teacher to complete the teaching task in the teaching process, and to realize the teaching goal. This ability includes how to stimulate students' enthusiasm and motivation in the teaching process. How to use the language skills, body movements to stimulate the interests of students, better collective teaching. As well as how to cultivate students' personality is greater.

\section{4 teaching monitoring abilities}

The ability of teaching monitoring refers to the ability of teachers to cope with the overall situation of teaching, to resist the interference and to respond to sudden changes in the teaching process. On the one hand, it is necessary for teachers to have the ability to detect and control the situation, and also needs teachers to have a certain degree of awareness and control ability. In addition, teachers' ability of self reflection is also essential.

\section{The application of young teachers in Colleges and universities teaching problems}

Teaching ability mainly refers to the ability of teachers to finish the teaching work smoothly, to achieve the teaching objectives, and to improve the efficiency of teaching activities. This ability is formed in the practice teaching process of teachers, and it is the necessary ample ability for teachers to do the teaching work. 
At present, the domestic and foreign research on young teachers' teaching ability is divided into 3 stages.[2]

The first stage in the 80 s of the last century after the reform and opening up to the beginning of the early 90s. At this stage, we should pay great attention to the cultivation and improvement of the ability of young teachers. In addition, the concept of fresh teachers' teaching ability is in its infancy. In addition, the evaluation system for young teachers has not yet been established, but there have been precise evaluation. The second stage is from the middle of 1990s to the pure expansion (the beginning of this century). This stage is the period of new and old alternation of higher education workers. In this case, the quality of higher education has attracted more and more attention. The main research contents of this stage are to study the measures to improve the cultivation of teaching ability of young teachers, young teachers also constitute for specific teaching ability is discussed, and the evaluation system for the teaching ability of young university teachers. The third stage is from the beginning of this century now. The main characteristic of this stage is that the demand for talents is higher and higher. The research results of this stage mainly focus on the construction of distinctive teaching ability evaluation index.

In Applied Undergraduate Colleges and universities, the main force for fledgling teachers under the age of 35. And in these young teachers, a considerable proportion of young teachers are not normal graduates. Therefore, there are some deficiencies in the training of teaching skills. Although in the formulation of national policy, the requirements of the new gang teachers should conduct a certain time of pure job training, but the training content is relatively simple, short training time, training mode is not perfect, let the young teachers' training problems. Most of the young teachers through the practice of exploration, to gradually enrich their teaching ability. In addition, the workload of young teachers in Colleges and universities is relatively large, and the salaries of teachers are closely linked to the length of class hours. At present, most of the University's teaching evaluation system are gradually weakened, and the situation of teaching assistants is gradually reduced. The old teacher's guide to young teachers is omitted, which makes the young teachers have no way to get the guidance of the old teachers in time. In this case, the lack of training and guidance of young teachers of the mechanism and means, which has become the urgent task of teaching management in Colleges and universities.

\section{The application of young teachers in Colleges and universities to explore ways}

\section{1 implement strict access system}

It is extremely important to improve the ability of teachers to improve the access system. From the preparation stage of teaching, to the evaluation of teaching ability, and then the teaching effect. Colleges and universities should be in the system and the detailed system, establish perfect audit system, the basic teaching unit to carry out some training and examination of new teachers, mainly includes the assessment of the teaching content, teaching design and teaching methods and 
training. After passing the examination and approval of the basic teaching unit, the relevant departments of the school shall be reported to the applicable departments. After this, experts from the steering committee dispatch supervision inspection and assessment of the trial completed the preparatory work. Only after more than a series of practice and teacher assessment work, only qualified, complete the relevant teaching activities. If the applicable teachers did not pass the assessment, should be re training and audit. There should be moved by repeatedly.

\section{2 strengthen the training of new teachers}

Pure job training of university teachers focuses on education and psychology training. Whether it is pure job training or vocational training, including training in the production process, and work experience in the field of industry or engineering training cannot be put on the agenda. Because of the pure job training process cards and the degree of the training results are immediate. For young teachers, more is the acquisition of practical interests. The energy is mainly out of graduate school, took the opportunity to raise the academic degree and. Due to the improvement of the practice teaching ability, it is a slow process, and the profit is less. The last is often the young teachers' scientific research ability and academic level have been greatly improved, but compared with no progress of young teachers teaching ability. This is very unfavorable to the improvement of everyday teaching ability and the cultivation of applied talents. It is particularly important for vocational training and pure service teachers. On the one hand, we should focus on improving the form of training, on the other hand, to enrich the content of training. [3]

3.3 with the help of school enterprise cooperation platform, improve the effectiveness of teachers' practical teaching ability training

In the process of improving the teaching ability, the enterprise is a valuable resource, on the other hand, it is also an important platform. Strive to get involved in the enterprise is not easy, an effective way to take the "double bang" approach. The so-called double hang". On the one hand, teachers need to enterprise testing exercise, can improve the teachers' functional ability, also has brought vitality for the enterprise. On the other hand, the company's executives and workers can work as a part-time professor at the school, in the process of achieving mutual benefit and win-win. According to the actual needs of the school, the need to take the initiative to be involved in the work of young teachers in the field of professional dividends to the factory or enterprise, and strive to create opportunities. On the one hand, we can improve the comprehensive ability and practical ability of teachers, on the other hand, they can grasp the pragmatic application process, and be more skilled in imparting knowledge and skills to students. Specific participation in the work of the enterprise can include production organization, technical management, product development and technical transformation. At the same time can also be included into the pure job training for employees, on the other hand it can also improve the practical teaching ability training. The main purpose is for the enterprise's technical level. The level of equipment has a certain grasp. In addition, it can also organize skilled teachers to complete the management and maintenance of some 
equipment, improve the ability to solve practical problems. The cooperation between enterprises and institutions is a win-win plan, for the enterprise, the "intelligence" resources of colleges and universities enter into the enterprise in the process of cooperation, and provides support for the development of enterprises. On the other hand, enterprise executives and senior engineers to enter the University, in fact, the "embedded" personnel training. Bring into full play the advantages of enterprises and colleges and universities to train talents and achieve the goal of win-win.

3.4 strive for government support to achieve continuous improvement of teachers' ability

The government may, in accordance with its own strengths, such as the ability of macro regulation and control, guidance, coordination and supervision. These capabilities can be invoked as a booster to provide opportunities for school enterprise cooperation to create incentives. On the one hand, the government can be guided by the policy, and even set up pertinent laws to encourage and protect school enterprise cooperation, for enterprises to participate in the work of colleges and universities to provide help and support. Financial supports for the participation of school enterprise cooperation in certain financial subsidies or tax support. On the one hand, to improve the enthusiasm of the participation of enterprises, on the other hand, it also provides protection of enterprises to participate in the process of school enterprise cooperation. Local governments need to come forward to sign the applicable agreements to support local enterprises and colleges and universities to carry out cooperation related research. Give attention to the training of "double qualified teachers". It is necessary in order to pay more attention to the enterprises with higher influence in the industry, and to set up the teacher training base in order to improve the ability of the teachers in the enterprise. Three are to establish the relevant system, to evaluate the teaching quality of teachers and the corresponding training. Four are to lift the barriers between enterprises and colleges and universities, so that talent can freely flow in the two, allowing enterprises to enter the college work, create value.[4]

3.5 improve the evaluation system, give full play to the guidance of teachers' practical teaching ability

Application oriented Undergraduate Colleges and universities pay more attention to the cultivation of practical ability in the process of cultivating talents. If it is necessary to ensure that the teachers to enhance the intrinsic motivation of teaching ability, it needs a relatively scientific and rigorous evaluation system, so that the evaluation system plays a guiding role. At present, university teachers have the perfect scientific research ability and the theory accomplishment appraisal standard, but lack the related appraisal system for the University Teachers' practical teaching ability. Education authorities have not issued pertinent documents to regulate this. Therefore, it is necessary in order to investigate the ability of teaching practice in the scope of the overall ability of teachers. This can form an effective mechanism on the level of teaching evaluation, restrain teachers to improve their teaching practice ability. In order to implement the training system of teachers' ability. 


\section{Concluding remarks}

Teachers' teaching ability training process is a slow process, cannot be completed in a short period of time. The promotion of teachers' practical ability is not only one aspect of the work can be accomplished, the need for cooperation from many angles to complete. In a word, the enthusiasm and initiative of teachers are the core and core of teaching ability. Therefore, the majority of teachers understand the importance of practical teaching ability in the teaching process of application oriented Undergraduate Colleges and universities. Young teachers should have taken the initiative to join and participate in the process of teaching ability promotion and training. In addition, the participation of enterprises and government also plays a positive role in promoting. On the importance of the teachers' practical teaching ability, it is also associated with the social development and the transformation of the talent structure in our country. And the transformation from the talent to the controlling country. Therefore, it is extremely important to study the significance of the cultivation and promotion of teachers' practical teaching ability.

\section{Acknowledgements}

The research work was supported by 2016 Hubei Teaching Resesrch Project of the Education Department: Research on the Development of Teachers' Teaching Ability in Applied Undergraduate Universities(provincial and ministerial level), No. 2016444.

\section{References}

[1] Clarke A, Hulbert S, Envisioning the Future: Working toward Sustainability in Fine Art Education. International Journal of Art \& Design Education, 35(1),pp:36 - 50,2016.

[2]Sun L, Windle M, Thompson N J, An Exploration of the Four-Factor Structure of the Drinking Motives Questionnaire-Revised Among Undergraduate Students in China. Substance Use \& Misuse, 50(12),pp:1-9, 2015.

[3]Hayden H E, Chiu M M, Reflective Teaching via a Problem Exploration-Teaching Adaptations--Resolution Cycle: A Mixed Methods Study of Preservice Teachers' Reflective Notes. Journal of Mixed Methods Research, 9(2),pp:133153,2015 .

[4]Hidi S, Revisiting the Role of Rewards in Motivation and Learning: Implications of Neuroscientific Research. Educational Psychology Review, 28(1),pp:1-33,2016. 